\title{
Monsanto: partnering for sustainable agriculture
}

\author{
Leigh English \\ From 5th Congress of the Brazilian Biotechnology Society (SBBIOTEC) \\ Florianópolis, Brazil. 10-14 November 2013
}

Monsanto is driven by a global commitment to sustainable agricultural production. This commitment includes bringing technologies to farmers that improve their lives by helping them be more productive while using fewer resources-leading to a reduced overall effect on the environment. By using this commitment to drive our actions, we believe we are creating a positive impact on our world.

But, we cannot do this alone. That's why, in addition to developing our own products, we also partner and collaborate with others to develop technologies for farmers. We also license our biotech traits and germplasm to other seed companies, giving farmers the opportunity to purchase seed technologies in the brands they choose.

External technology collaborations are a key to our promise of delivering innovative new products in the future. At Monsanto, we are focused on developing collaborative alliances that product lasting benefits for our farmer customers and all involved [1].

Published: 1 October 2014

\section{Reference \\ 1. Monsanto[http://www.monsanto.com/whoweare/pages/partner-with- monsanto.aspx].}

Submit your next manuscript to BioMed Central and take full advantage of:

- Convenient online submission

- Thorough peer review

- No space constraints or color figure charges

- Immediate publication on acceptance

- Inclusion in PubMed, CAS, Scopus and Google Scholar

- Research which is freely available for redistribution

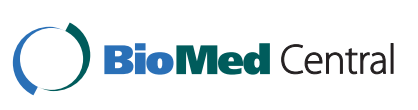

(c) 2014 English; licensee BioMed Central Ltd. This is an Open Access article distributed under the terms of the Creative Commons Attribution License (http://creativecommons.org/licenses/by/4.0), which permits unrestricted use, distribution, and reproduction in any medium, provided the original work is properly cited. The Creative Commons Public Domain Dedication waiver (http:// creativecommons.org/publicdomain/zero/1.0/) applies to the data made available in this article, unless otherwise stated. 